\title{
Study on the Prevention and Control of Infections in Dental Practice in Health Units of Luanda
}

\author{
Estudo sobre a Prevenção e Controlo de Infeções na Prática Odontológica em Unidades \\ Sanitárias de Luanda
}

\author{
Teresa Dalbertina Macosso ${ }^{1,2}$, Ana Resendes ${ }^{1}$, Alberto Paca Macosso ${ }^{3}$, Manuel Londa Vueba ${ }^{2}$, Maria do \\ Céu Costa ${ }^{1}$ \\ ${ }^{1}$ CBIOS, Escola de Ciências e Tecnologias da Saúde, Universidade Lusófona, Campo Grande 376,1649-024 Lisboa, \\ Portugal \\ ${ }^{2}$ Departamento de Saúde Pública da Universidade Privada de Angola, Luanda \\ ${ }^{3}$ Governo da Província de Cabinda, Angola \\ e-mail: dalbertinateresa@hotmail.com
}

\begin{abstract}
The purpose of this study was to identify the problems arising from the importance attributed to the control of infections in dental practice in Luanda. An analytical, descriptive, and prospective study was designed to establish a cause and effect relationship based on an original semi-structured interview form with open and closed questions. In the sample, consisting of 28 dental professionals and 7 managers of dental care units, more than $75 \%$ were fully satisfied or satisfied with the notions of microbiology, $82 \%$ reported having had laboratory practice and $86 \%$ considered receiving knowledge during training to perform their activity. However, $86 \%$ did not receive any continuous training in the last three years. Infection Control Committees are operational, but in $71 \%$ of the cases there are no records of the Commissions' work reports or any microbiological mapping.
\end{abstract}

Keywords: Biosecurity, Dentistry, Infection Control

\begin{abstract}
Resumo
Tendo por objetivo conhecer os problemas decorrentes da importância atribuída ao controlo de infeções na prática odontológica em Luanda, foi desenhado um estudo analítico, descritivo e prospetivo, para estabelecer uma relação causa-efeito, com base num formulário original de entrevista semiestruturada, com perguntas abertas e fechadas. $\mathrm{Na}$ amostra, constituída por 28 profissionais de odontologia e 7 gestores de unidades de assistência odontológica, mais de $75 \%$ estavam totalmente satisfeitos ou satisfeitos com as noções de microbiologia, $82 \%$ referiram ter tido prática laboratorial e $86 \%$ consideram terem recebido conhecimentos suficientes durante a formação para o desempenho da sua atividade. Porém, $86 \%$ não recebeu qualquer formação contínua nos últimos 3 anos. Existem em funcionamento Comissões de Controlo de Infeção, mas em $71 \%$ dos casos não existem registos de relatórios de trabalho das referidas Comissões, nem de qualquer mapeamento microbiológico.
\end{abstract}

Palavras-chave: Biossegurança, Odontologia, Controlo de Infeção. 


\section{Introduction}

For years, there have been recommendations for improving biosafety in clinics, but some practitioners are still resistant to adopting infection control measures, although patients themselves are aware of the real danger of visiting a dentist who does not meet the standards of security. After the appearance of Acquired Immunodeficiency Syndrome (AIDS) in the early 1980s, health communities were alerted to the real danger of occupational transmission of infectious diseases, and a strong movement was initiated towards cross-infection in health services to reduce risks for both professionals and patients ${ }^{[1]}$.

Prior to the care given to the new patient, effective measures must be taken to prevent the chain of crossinfection ${ }^{[2]}$ All equipment handled by the dental surgeon and his or her team may be contaminated. It is advisable to systematically disinfect the surfaces with $70 \%$ alcohol (or $770 \mathrm{GL}$ ), synthetic compounds based on iodine, alcoholic solution of chlorhexidine (2 to $5 \%$ in $70 \%$ alcohol), phenolic compounds or sodium hypochlorite $(0.5 \%)$ according to the surface material ${ }^{[2]}$. According to ANVISA, ${ }^{[3]}$ the Brazilian Health Regulatory Agency, health managers have increased their awareness of the importance of incorporating appropriate technologies for the control of infection and biosafety, providing resources to improve care and promoting the permanent education of teams and the population.

In order for the dentist to effectively control dental infection during clinical procedures, it is necessary to create a classification of clinical instruments and procedures for the risk of transmitting exogenous infection. An adaptation of Spaulding's classification for hospital materials and equipment in critical, semicritical and non-critical, that can also be adopted for dental instruments, ${ }^{[4]}$ is a reference.

With regard to the prevention of cross-infection, it is done by the use of sterilization processes and all procedures designed to maintain the aseptic chain. Such procedures are performed in relation to dental personnel, instruments and accessories, equipment and patient. It can be said that stopping infections in dental offices is one of the great challenges for dentists, researchers and immunologists. The lack of care of some professionals in relation to biosafety has led to an intensification of the cycle of cross-infection ${ }^{[5,6]}$.To perform effective infection control during patient care, the dentist and his team must follow a series of basic measures. Specific questions about the current and previous medical history, medications being taken, systemic diseases (diabetes, hepatitis, heart disease, tumors, epilepsy, or-

\section{Introdução}

Há anos existem recomendações para a melhoria da biossegurança nos consultórios, mas parte dos profissionais ainda se mostra resistente à adoção de medidas de controlo de infeção, embora os próprios pacientes mostrem ter consciência do real perigo de uma visita a um dentista que não cumpre as normas de segurança. Depois do aparecimento do Síndrome de Imunodeficiência Adquirida (SIDA), no início da década de 80, as comunidades de saúde foram alertadas para o real perigo da transmissão ocupacional de doenças infeciosas, iniciando-se um forte movimento para adoção de um programa para controlo de infeção cruzada nos serviços de saúde, destinado a reduzir os riscos tanto para profissionais quanto para pacientes ${ }^{[1]}$.

Antes do atendimento ao novo paciente, medidas eficazes devem ser tomadas para impedir a cadeia de infeção cruzada $^{[2]}$. Todos os equipamentos manuseados pelo cirurgião dentista e sua equipa poderão estar contaminados. Preconiza-se fazer uma desinfeção sistemática das superfícies com álcool 70\% (ou 770 GL), compostos sintéticos à base do iodo, solução alcoólica de clorexidina (2 a 5\% em álcool a 70\%), compostos fenólicos ou hipoclorito de sódio $(0,5 \%)$ de acordo com o material da superfície ${ }^{[2]}$. Segundo a ANVISA- ANVISA - Agência Nacional de Vigilância Sanitária ${ }^{[3]}$, os gestores de saúde têm aumentado a sua consciencialização para a importância da incorporação de tecnologias apropriadas para o controlo de infeção e biossegurança, provendo recursos para a melhoria da assistência e promovendo a educação permanente das equipas e da população. Para que o dentista mantenha efetivo controlo de infeção odontológica durante a realização dos procedimentos clínicos, é necessária a criação de uma classificação dos instrumentos e dos procedimentos clínicos quanto ao risco de transmitirem infeção exógena. Constitui referencial uma adaptação da classificação de Spaulding para materiais e equipamentos hospitalares em: críticos, semicríticos e não-críticos, que pode também ser adotada para os instrumentos odontológicos ${ }^{[4]}$.

No que respeita à prevenção da infeção cruzada, é feita pelo emprego dos processos de esterilização e de todos os procedimentos destinados a manter a cadeia asséptica. Tais procedimentos são realizados em relação ao pessoal odontológico, aos instrumentos e aos acessórios, ao equipamento e ao paciente. Pode-se dizer, que reduzir as infeções nos consultórios odontológicos é um dos grandes desafios para cirurgiões-dentistas, investigadores e imunologistas. A falta de cuidado de alguns profissionais em relação à biossegurança tem propiciado a intensificação do ciclo de infeções cruza- 
thopedic prostheses), blood transfusions, transplants, physiological conditions (lactation and gestation) and others, should be considered in their first clinical evaluation with the professional and in the remaining consultations ${ }^{[4]}$.

According to Freitas ${ }^{[7]}$ even with all biosafety measures implemented, occupational accidents may occur with the oral health team, with more cases being reported with HIV / AIDS (Human Immunodeficiency Virus, a lentivirus that is the origin of the Acquired Immunodeficiency Syndrome), Hepatitis B HBV (Hepadnavirus with circular double-stranded DNA genome and strong predilection for hepatocyte liver infection) and Hepatitis $\mathrm{C} \mathrm{HCV} \mathrm{(common} \mathrm{cause} \mathrm{of} \mathrm{chronic} \mathrm{hepatitis,} \mathrm{with}$ hepatitis $\mathrm{C}$ being a viral disease leading to inflammation of the liver, that can be transmitted sexually and parenterally). When injured, the professional should promote soap and water washing in the affected area, and in case of injury, promote the drying and passage of antiseptic based on PVPI (Iodopovidone or Povidone-iodine) or $2 \%$ chlorhexidine, and in no case use disinfectants that cause irritations, such as hypochlorite, glutaraldehyde or phenolic compounds.

Biosafety in dentistry is defined as being a set of preventive measures that involve the disinfection of the environment, the sterilization of the instruments and the use of personal protective equipment (PPEs), by the professional and team ${ }^{[8]}$. Here the highlight is for PPE (the cap, goggles, mask, apron or office clothing, gloves, shoes or shoe for exclusive use in the office), not only for the professional but also for the auxiliary personnel and, still, the physical and chemical methods in the sterilization of the dental materials.

Cottone and Molinari ${ }^{[9]}$ emphasize that blood presents a greater risk of contamination, and that it should not be forgotten that several microorganisms, such as hepatitis, herpes, rubella, among others, are transmitted through saliva.

In dentistry there are difficulties in associating the appearance of infectious diseases to the care given due to the incubation period observed in some diseases, such as hepatitis, for example, leading some researchers to affirm that the transmission of diseases through professional-patient should be more frequent than those reported in the literature ${ }^{[8]}$.

Clinical and surgical dental procedures are classified according to risk of contamination, namely:

- Critical procedures are those in which there is penetration into the vascular system (e,g.,: soft and hard tissue surgery, periodontal surgeries, exodontia, subgingival scaling or periodontal choreography, etc). In these procedures, the care with sterilization and disinfection of das ${ }^{[5,6]}$. Para a realização do controlo de infeção efetivo, durante o atendimento do paciente, o dentista e sua equipa devem seguir uma série de medidas básicas. Devem considerar-se questões específicas sobre a história médica atual e prévia, medicamentos que o paciente esteja tomando, de doenças sistémicas (diabetes, hepatite, cardiopatias, tumores, epilepsia, próteses ortopédicas), transfusões sanguíneas, transplantes, condições fisiológicas (lactação e gestação) e outras, tanto na sua primeira avaliação clínica com o profissional como nas restantes consultas ${ }^{[4]}$.

De acordo com Freitas ${ }^{[7]}$, mesmo com todas as medidas de biossegurança implementadas, podem ocorrer acidentes ocupacionais com a equipa de saúde bucal, sendo mais relatados casos de contaminação com o HIV/SIDA (Vírus da Imunodeficiência Humana, um lentivírus que está na origem da Síndrome da Imunodeficiência Adquirida), o HBV da Hepatite B (Hepadnavirus com genoma de DNA bicatenar circular e predileção forte pela infeção dos hepatócitos do fígado) e o HCV da Hepatite C (causa comum de hepatite crónica, sendo a hepatite $\mathrm{C}$ uma doença viral que leva à inflamação do fígado, podendo ser transmitida sexual e parentericamente). Ao ser acidentado, o profissional deve promover lavagem em água corrente com sabão na área acometida, e caso haja ferimento, promover a secagem e passagem de anti-séptico à base de PVPI (Iodopovidona ou Povidona-iodo) ou clorexidina a $\%$, não fazendo uso em hipótese alguma de desinfetantes que causam irritações, como o hipoclorito, glutaraldeído ou compostos fenólicos.

Biossegurança em odontologia é definida como sendo um conjunto de medidas preventivas que envolvem a desinfeção do ambiente, a esterilização do instrumental e o uso de equipamentos de proteção individual (EPI's), pelo profissional e equipa ${ }^{[8]}$. Aqui o destaque vai para os EPI (o gorro, os óculos de proteção, máscara, avental ou roupa própria do consultório, luvas, sapatilhas ou sapato de uso exclusivo no consultório), não só para o profissional como também para o pessoal auxiliar e, ainda, os métodos físicos e químicos na esterilização dos materiais odontológicos.

Cottone e Molinari ${ }^{[9]}$ salientam que o sangue apresenta um maior risco de contaminação, e que, não se deve esquecer a possibilidade de diversos microrganismos, tais como o vírus da hepatite, herpes, rubéola, entre outros, também serem transmitidos através da saliva.

$\mathrm{Na}$ odontologia existem dificuldades em associar o surgimento de doenças infeciosas aos atendimentos realizados, devido ao período de incubação observado em algumas doenças, tal como a hepatite, por exemplo, levando alguns pesquisadores a afirmar que a transmissão 
the instruments and the dental office and preparation of the patient and dental team must be maximum.

- Semi-critical procedures: when they come in contact with organic secretions (saliva) without invading the vascular system (e.g., insertion of restorative material, conservative endodontic therapy, orthodontic appliance placement). The instrument panel must be previously sterilized and the clinic disinfected to avoid cross-infection by the presence of organic secretions on the instruments and by the production of aerosols during the procedures.

- Non-critical procedures: when there is no contact with organic secretions or penetration into the vascular system. In Dentistry, there is no procedure that can be classified in this category ${ }^{[8]}$.

Pathogens can be transferred from the oral cavity of patients to dental equipment through direct contact, by other instruments, and by splashing of body fluids such as blood and saliva. Cross contamination is aggravated by many types of dental equipment, primarily the use of high and low rotation pens, producing aerosols (liquid and solid particles suspended in the air), promoting the dissipation of the microorganisms for about one meter of the operative field, making the equipment and the surfaces of the surgery area contaminated ${ }^{[2]}$.

It is therefore considered important to know the problems arising from infection control programs in dental practice. For this purpose, the following specific objectives were defined: i) to identify whether or not there is a lack of knowledge of professionals and dental assistants regarding the transmission of infections during dental practice; ii) characterize the observance of biosafety measures in dental practice in the units; iii) to know the managers' perception regarding the availability of PPE; iv) identify management problems, if any, that result in insufficient PPE . Finally, support for Infection Control Plans should be based on site map in the dental clinic where the screening samples were obtained, helping to recognise the potential of critical points for the development of the microbiological flora - what we call microbiological mapping.

\section{Material and methods}

\section{Field of study}

The study was carried out in 7 units with dental assistance, of which 3 were public (Josina Machel Hospital, Prenda Hospital, Samba Municipal Hospital) and 4 private (Clinica Dental Center, Adventist Dental Clinic, Cliang Clinic and International Clinic). de doenças através dos contactos profissional-paciente-auxiliares, devem ser mais frequentes do que a registada pela literatura ${ }^{[8]}$.

Os procedimentos odontológicos clínicos e cirúrgicos são classificados segundo risco de contaminação em:

- Procedimentos críticos: são aqueles em que há penetração no sistema vascular (Ex: cirurgia em tecidos moles e duros, cirurgias periodontais, exodontias, raspagens subgengival ou coretagem periodontal, etc. Nestes procedimentos os cuidados com a esterilização e desinfeção do instrumental e do consultório e preparação do paciente e equipa odontológicos devem ser máximos.

- Procedimentos semicríticos: quando entram em contacto com secreções orgânicas (saliva) sem invadir o sistema vascular (Ex: inserção de material restaurador, terapia endodôntica conservadora, colocação de aparelho ortodôntico). O painel instrumental deve estar previamente esterilizado e o consultório desinfetado para evitar infeções cruzadas pela presença das secreções orgânicas sobre os instrumentais e pela produção de aerossóis durante os procedimentos.

- Procedimentos não-críticos: quando não há contacto com secreções orgânicas nem penetração no sistema vascular. Na Odontologia não existe nenhum procedimento que possa ser classificado nessa categoria ${ }^{[8]}$.

Os agentes patogénicos podem ser transferidos da cavidade oral dos pacientes para os equipamentos odontológicos por meio de contacto direto, por via instrumental e por respingo de fluídos corporais tais como sangue e saliva. A contaminação cruzada agrava-se através de muitos equipamentos usados em odontologia, principalmente o uso das canetas de alta e baixa rotação, ocorrendo a produção de aerossóis (partícula líquida e ou sólida suspensa no ar), promovendo a dissipação dos microrganismos, por cerca de um metro do campo operatório, tornando os equipamentos e as superfícies do consultório contaminados ${ }^{[2]}$.

Considera-se, assim, importante conhecer os problemas decorrentes dos programas de controlo de infeções na prática odontológica. Para o efeito definiram-se como objetivos específicos deste estudo: i) Identificar se existe ou não défice do conhecimento dos profissionais e auxiliares de odontologia relativamente à transmissão de infeções no decorrer da prática odontológica; ii) Caracterizar a observância das medidas de biossegurança na prática odontológica nas unidades; iii) Conhecer a perceção dos gestores quanto à disponibilização de EPI's; iv) Identificar, em caso de existirem, problemas que levam gestores a disponibilizarem insuficientemente os EPI's. Finalmente, o suporte para os planos de controlo de infeções, devem estar estabelecidos em mapa de locais na clínica odontológica onde as amostras de triagem foram obtidas, ajudando a perceber o 
Type of study

An analytical, prospective study was carried out to establish a cause-and-effect relationship, and confidently extrapolate to the clinical realm the results obtained from sampling.

\section{Study Design}

Since this work intended to study a unique reality in order to provide evidence and to verify the factors that may interfere in it, the research project design was composed by the following stages: contextualization of the questions of the study in light of the bibliographical survey, definition of the hypothesis and objectives of the study, choice of the clinical realm and consequently the population surveyed, chosen through the causal sampling method (stratified), preparation and application of the original questionnaire prepared and validated.

The collection and introductory statistical treatment of the data was performed using the statistical software SPSS (Statistical Package for Social Sciences) Version 25 .

The research questions defined were as follows:

- What is the knowledge of dentistry professionals and auxiliaries regarding the infections transmitted during the practice of dentistry?

- What biosafety measures are observed in dental practice in dental care units?

- What is the perception and reality of managers regarding the availability of PPE's in dental care units?

For the purposes of data processing and statistical analysis, we used the Epi-Info 7.1 program, a descriptive method for quantitative and qualitative variables (frequencies), and verified the association between training and variables of interest, using the Chi-Mantel-Haenszel Square and Fisher's Exact Test.

\section{Study Clinical Realm}

The target clinical realm in this study was made up of dentists, dental assistants and managers of dental care units in the city of Luanda.

\section{Sample}

The sample was composed of 20 dentists, 15 dentistry assistants and 7 managers, selected by non-proportional stratified probabilistic method, and who function in seven of the various dental care units in the city of Luanda. Theywere randomly selected, using random technique, in the month of June 2016, in five consecutive days. potencial de pontos críticos para o desenvolvimento da flora microbiológica - aquilo que designamos como mapeamento microbiológico.

\section{Material e Métodos}

\section{Campo de Estudo}

O estudo foi realizado em 7 unidades com assistência odontológica, das quais 3 públicas (Hospital Josina Machel, Hospital do Prenda, Hospital Municipal da Samba) e 4 privadas (Clinica Dental Center, Clinica Dentária Adventista, Clinica Cliang e Clinica Internacional).

\section{Tipo de Estudo}

Foi realizado um estudo analítico, prospetivo, com a finalidade procurar estabelecer relação causa-efeito, extrapolando com confiança para o universo, os resultados obtidos a partir da amostra.

\section{Desenho do Estudo}

Dado que este trabalho pretende estudar e evidenciar uma realidade única e verificar os fatores que nela interferem, esta pesquisa ficou composta pelas seguintes etapas: Contextualização das questões do estudo à luz do levantamento bibliográfico; Definição da hipótese e objetivos do estudo; Escolha do universo e consequentemente a população inquirida, escolhida através do método de amostragem causal (estratificado); Elaboração e aplicação do questionário original preparado e validado.

A Recolha e introdução Tratamento estatístico dos dados foi realizada utilizando o software estatístico SPSS (Statistical Package for Social Sciences) Versão 19.

As questões de investigação definidas foram as seguintes:

- Qual é o conhecimento dos profissionais e auxiliares de odontologia quanto às infeções transmitidas no decurso da prática odontológica?

- Que grau de observância das medidas de biossegurança na prática odontológica nas unidades de assistência odontológica?

- Qual a perceção e a realidade dos gestores quanto a disponibilização de EPI's nas unidades de assistência odontológica?

Para efeitos de processamento e análise estatística de dados foi utilizado o programa Epi-Info 7.1, método descritivo para variáveis quantitativas e qualitativas (frequências), e foi verificada a associação entre a formação e variáveis de interesse, utilizando-se os testes de Qui-Quadrado de Mantel-Haenszel e o Teste Exacto de Fisher. 


\section{Inclusion criteria}

- To be a dentist, dental assistant and manager of a dental care unit in the city of Luanda;

- be at least 18 years of age;

- Accept voluntary participation in the study by signing the informed consent form.

Nature of Study Variables

Quantitative: Age

Qualitative: Gender, marital status, training on nosocomial infections, operative plans on infection control, infection control committees

\section{Ethical Procedure}

Permission was granted from the institutions to apply a questionnaire to professionals and dental assistants and the purpose of the study was explained. The research was approved by the Academic Area of the Private University of Angola, thus ensuring the full cooperation of the authorities. It was also requested the authorization of the institutions and collaboration of the participants in this research and agreement with the publication of the results, preserving, in this way any ethical and legal inconveniences.

\section{Results}

\section{Sociodemographic characteristics}

Data from all 28 questionnaires applied in this study were considered valid. Regarding the age group, the results show that the mean was 37 years and that the highest percentages are in the age group from 41 to 50 years (21\%) and in the age group from 31 to 40 years (18\%).

\section{Universo do estudo}

O universo alvo neste estudo foi constituído por odontologistas, auxiliares de odontologia e gestores das unidades da assistência odontológica da cidade de Luanda.

\section{Amostra}

A amostra inquirida foi composta por 20 Odontologistas, 15 auxiliares de odontologia e 7 gestores, selecionados por método probabilístico estratificado não proporcional, e que funcionam em 7 das diversas unidades de atendimento odontológico na cidade de Luanda, tendo sido escolhidos aleatoriamente, ou seja, pela técnica aleatória no mês de junho de 2016, em 5 dias consecutivos.

\section{Critérios de Inclusão}

- Ser odontologista, auxiliar de odontologia e gestor de uma unidade de assistência odontológica da cidade de Luanda;

- Ter idade igual ou superior a 18 anos;

- Aceitar participar voluntariamente no estudo, assinando o termo de consentimento informado.

\section{Natureza das Variáveis do Estudo}

Quantitativa: Idade

Qualitativas: Género, Estado civil, Formação sobre infeções nosocomiais, Planos operativos sobre controlo de infeção, Comissões de controlo de infeção.

\section{Procedimento Ético}

Foi obtida, das instituições, a permissão para aplicar um questionário aos profissionais e auxiliares de odontologia e o propósito do estudo foi explicado. A pesquisa foi aprovada pela Área Académica da Universidade Privada de Angola, assegurando assim a inteira colaboração das autoridades. Também foi solicitada a autorização das instituições e colaboração dos participantes nesta pesquisa e concordância com a publicação dos resultados, preservando, desta forma quaisquer inconvenientes éticos e legais.

\section{Resultados}

\section{Características sociodemográficas}

Foram analisados os dados de todos os 28 questionários aplicados neste estudo, considerados válidos. A média de idades dos respondentes foi de 37 anos sendo maioritária a faixa etária de 41 a 50 anos (21\%), seguida da faixa etária dos 31 a 40 anos (18\%). Mais de um terço 
The remaining 39\% did not report their age at the time of application of the questionnaire.

The participants in the study were predominantly female $(57 \%)$, with $32 \%$ male and $11 \%$ not referring their gender (Figure 2). dos inquiridos, 39\%, optaram por não referir a sua idade na ocasião de aplicação do questionário.

Os participantes no estudo são predominantemente do género feminino (57\%), com $32 \%$ do género masculino, e $11 \%$ não referiram o género (Figura 2 ).

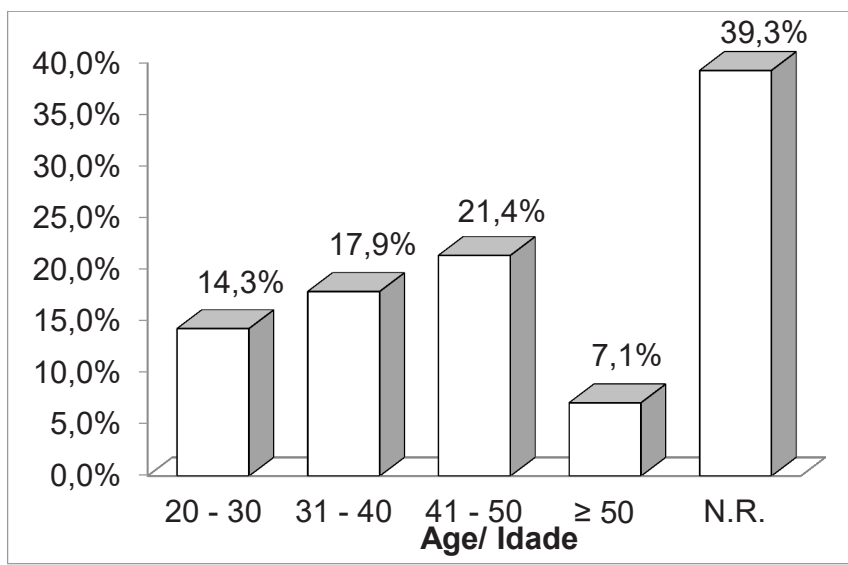

Figure / Figura 1 - Distribution of dentistry and auxiliar professionals by age group/ Distribuição dos profissionais e auxiliares de odontologia por faixa etária

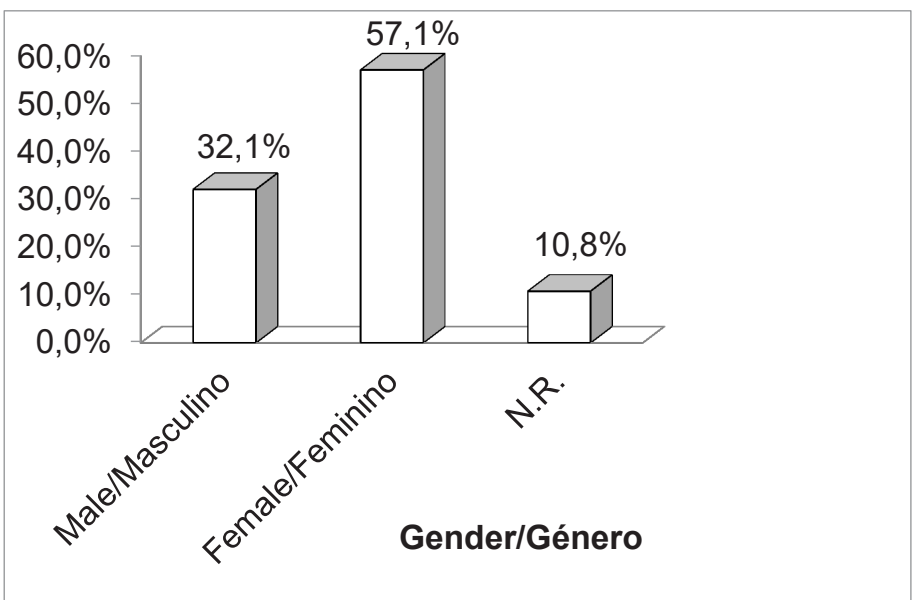

Figure 2/ Figura 2 - Distribution of dental professionals and auxiliaries by gender. / Distribuição dos profissionais e auxiliares de odontologia por género. 
Regarding marital status, 13 (46\%) of the participants reported being married, followed by 10 (36\%) singles, and a single one $(4 \%)$ reported being a widow. Four participants $(14 \%)$ did not report their marital status.
No que concerne ao estado civil, $13(46 \%)$ dos participantes relatam serem casados, seguindo-se $10(36 \%)$ solteiros, e um único (4\%) referiu ser viúvo. No entanto, entre os participantes 4 (14\%) não referiram sua situação conjugal.

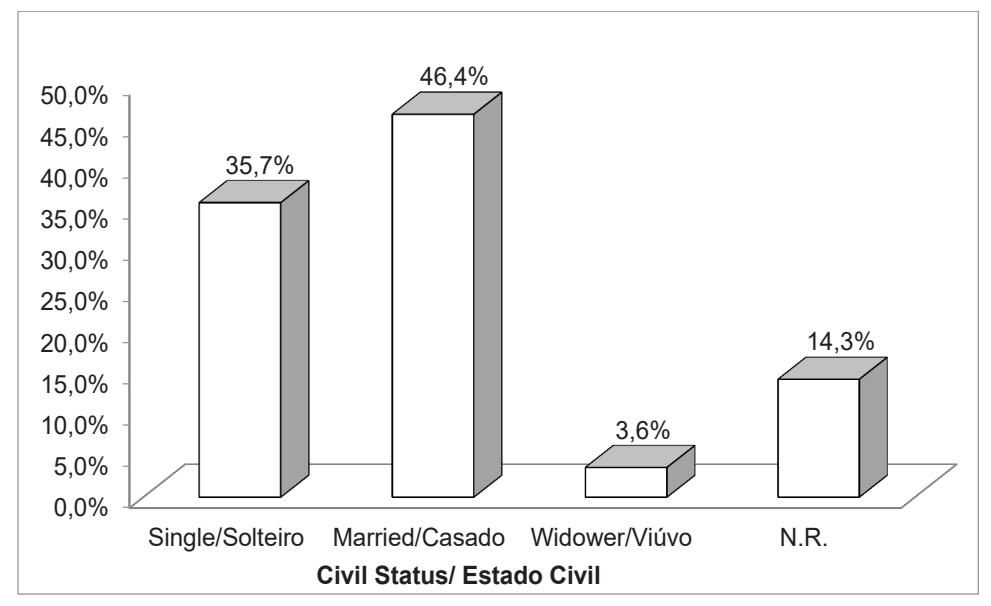

Figure 3/ Figura 3- Distribution of dental professionals and auxiliaries by civil status./ Distribuição dos profissionais e auxiliares de odontologia por estado civil.

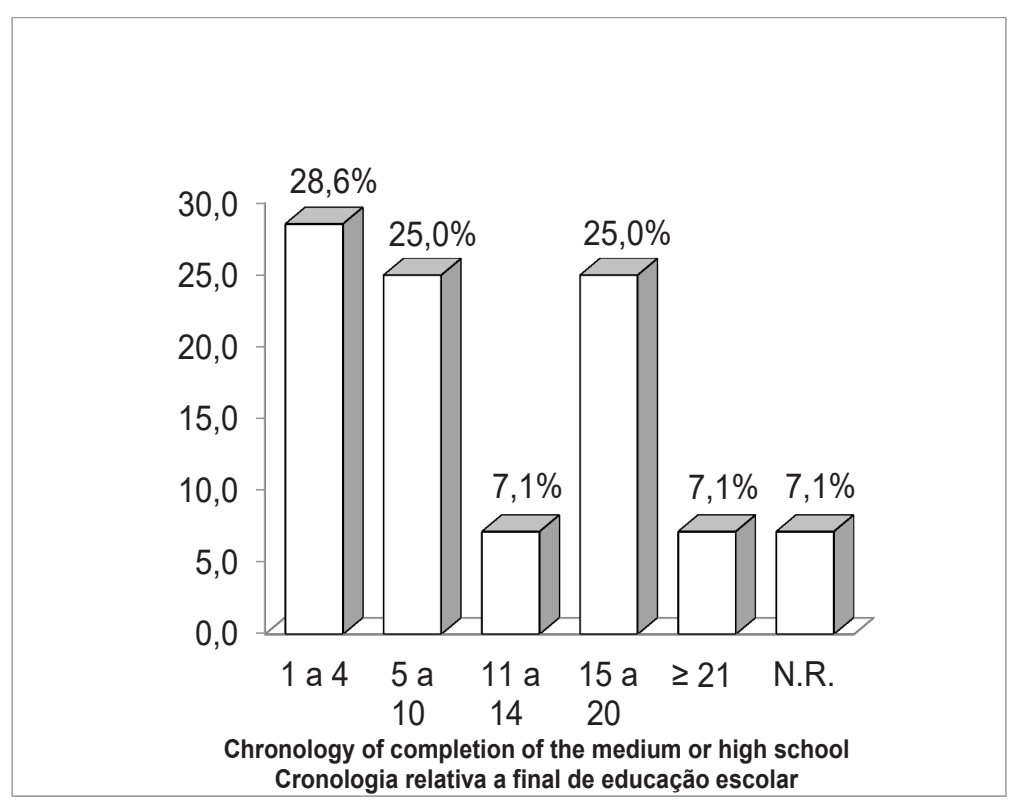

Figure 4/ Figura 4- Distribution of dentistry professionals according to the chronology of completion of the medium / high school years./ Distribuição dos profissionais de odontologia de acordo a cronologia por anos da conclusão do curso médio/superior. 
When asked how many years of education they had completed in high school or higher, the majority of subjects had completed between 1 and 4 years (29\%), followed by those with 5 to 10 years and 15 to 20 years $(25 \%)$, and $7 \%$ for those who had between 11 and 14 , $7 \%$ for more than 21 years, and $7 \%$ as well as for those who did not respond. The time elapsed since completing high school/ college ranged from a minimum of 1 year to a maximum of 32 years, with an average of 10 years ( + standard deviation of 8 years).

Of all the participants, $54 \%$ completed their courses in private institutions while $46 \%$ attended public educational institutions (Graph 5).

When the professional category was analysed, the dentists represented a total of $6(21 \%)$, the auxiliaries were $7(25 \%)$, and one of the participating technicians (4\%) did not mention its professional category (Graph 6).
Quando questionados há quantos anos concluíram o ensino médio ou superior, a maioria dos indivíduos tinha concluído entre 1 a 4 anos (29\%), seguindo-se os com 5 a 10 anos e 15 a 20 anos (25\%), e os que tinham concluído há um período de tempo entre 11 a 14 anos (7\%) igualavam os de há mais de 21 anos (7\%) e os que não responderam, 7\%. O tempo decorrido desde a conclusão do ensino médio/superior variou de um mínimo de 1 ano para um máximo de 32 anos, com uma média de 10 anos ( \pm desvio-padrão de 8 anos).

Dos participantes, $54 \%$ concluíram seus cursos em instituições privadas enquanto $46 \%$ frequentaram instituições públicas de ensino (Figura 5).

Quando analisada a categoria profissional, os odontologistas, representam um total de $6(21 \%)$, porquanto os auxiliares foram 7 (25\%) e um dos técnicos participantes (4\%) não referiu sua categoria profissional (Figura $6)$.

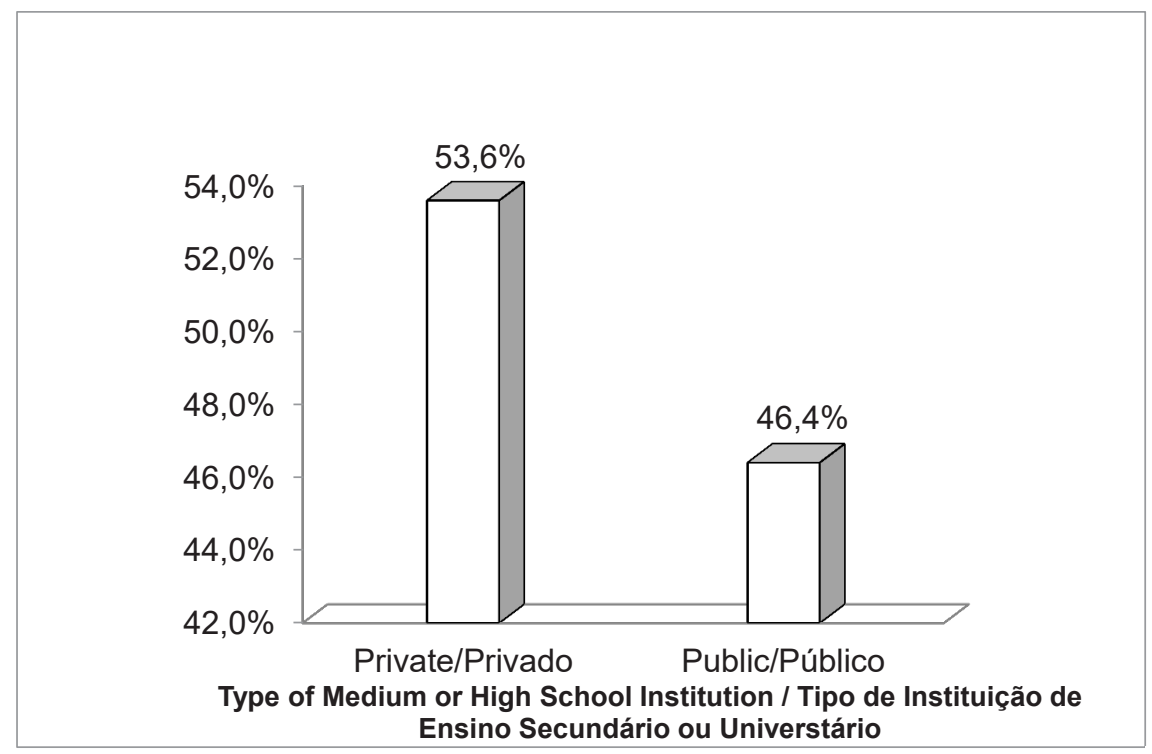

Figure 5/ Figura 5-Distribution of dentistry professionals according to the institution where they completed the medium - high school./ Distribuição dos profissionais de odontologia de acordo a instituição onde concluiu o curso médio-superior. 


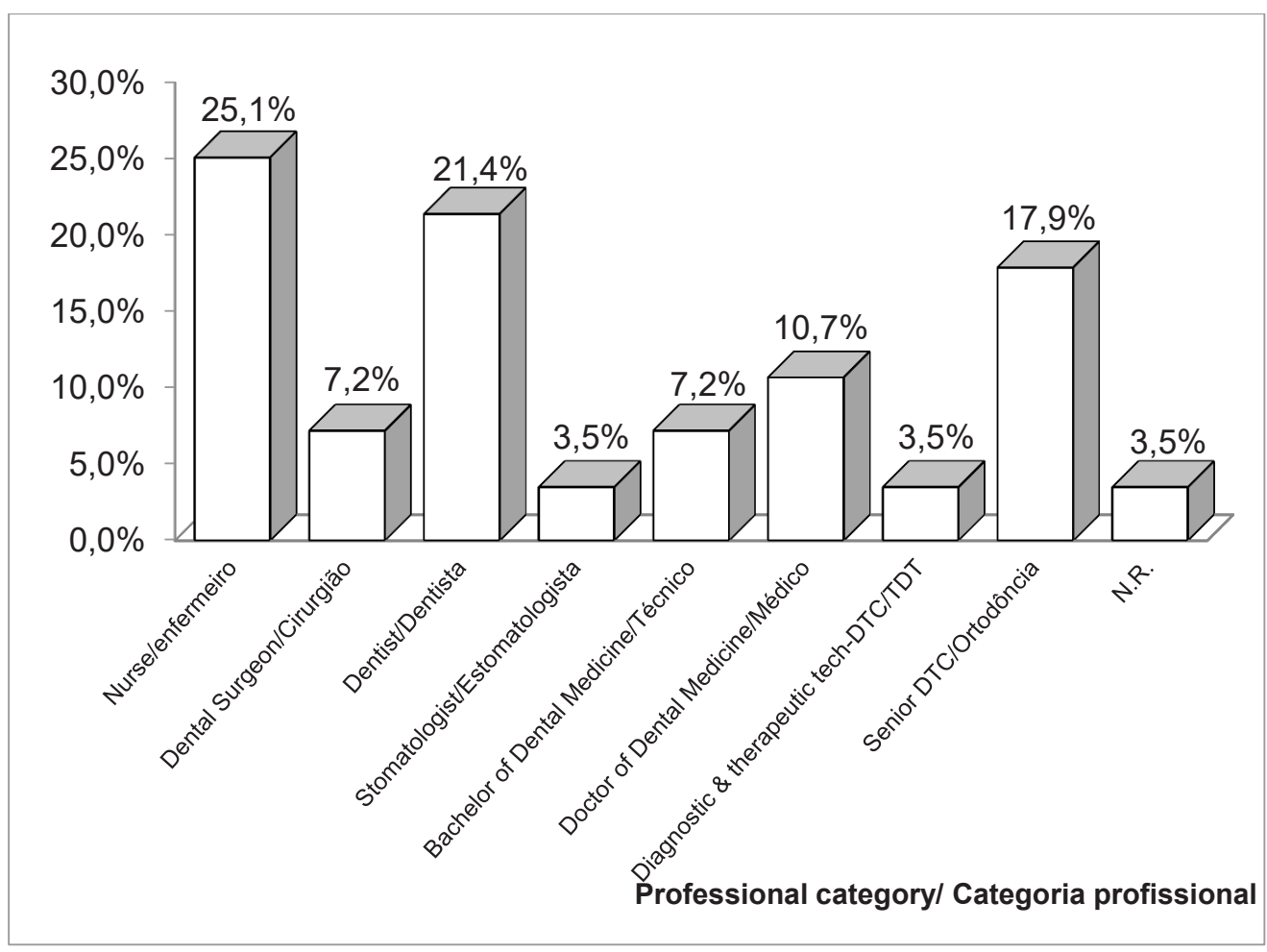

Figure 6/ Figura 6 - Distribuição dos profissionais de acordo a sua categoria profissional. /Distribution of professionals according to their professional category

As far as the acquired knowledge is perceived, 12 (43\%) of the respondents were completely satisfied with their knowledge, $9(32 \%)$ reported it to be satisfactory, 4 $(13 \%)$ described it as unsatisfactory, and for $3(11 \%)$ the knowledge was insufficient, as shown in Figure 7.

The results in Graph 8 indicate that $23(82 \%)$ of dental professionals and auxiliaries had laboratory practice during their training and 5 (18\%) did not.

Concerning the classification of knowledge acquired during training, a large majority of the participants (24 participants, $86 \%$ ) consider that they are sufficient for the performance of their daily professional activity (Graph 9). However, 4 (14\%) do not share this view.

In this study it was observed that $2(7 \%)$ of the respondents had the benefit of continuous training in microbiology in the last 3 years. Another $2(7 \%)$ were still attending this training and $24(86 \%)$ never benefited from any training in microbiology within their institutions (Graph 10).

Regarding the respondents' prior awareness of about the Commission for the Control of Infection, we found that $15(54 \%)$ had already heard about the Commission for the Control of Infection and $13(46 \%)$ denied having knowledge of the existence of this commission (Graph 11).
Sobre as noções de microbiologia recebidas durante a sua formação, observamos que 12 (43\%) dos inquiridos estavam totalmente satisfeitos com os conhecimentos, $9(32 \%)$ relataram serem satisfatórios, $4(13 \%)$ descreveram como sendo pouco satisfatórios e 3 (11\%) afirmaram que foram insuficientes, conforme mostra o Figura 7.

Os resultados no Figura 8 indicam que 23 (82\%) dos profissionais e auxiliares de odontologia tinham prática laboratorial durante a sua formação e 5 (18\%) não tiveram.

Relativamente à perceção da classificação dos conhecimentos adquiridos durante a formação, uma grande maioria dos participantes $24(86 \%)$ considera serem suficientes para o desempenho de sua atividade diária profissional (Figura 9). No entanto 4 (14\%) não partilham essa opinião.

Observou-se que 2 (7\%) dos inquiridos tiveram o benefício de uma formação contínua em microbiologia nos últimos 3 anos, enquanto outros 2 (7\%) ainda se encontram a frequentar essa formação e 24 (86\%) nunca beneficiaram de nenhuma formação contínua em microbiologia nas suas instituições (Figura 10).

Sobre o facto de os inquiridos terem ou não já alguma vez ouvido falar da Comissão de Controlo de Infeção, 


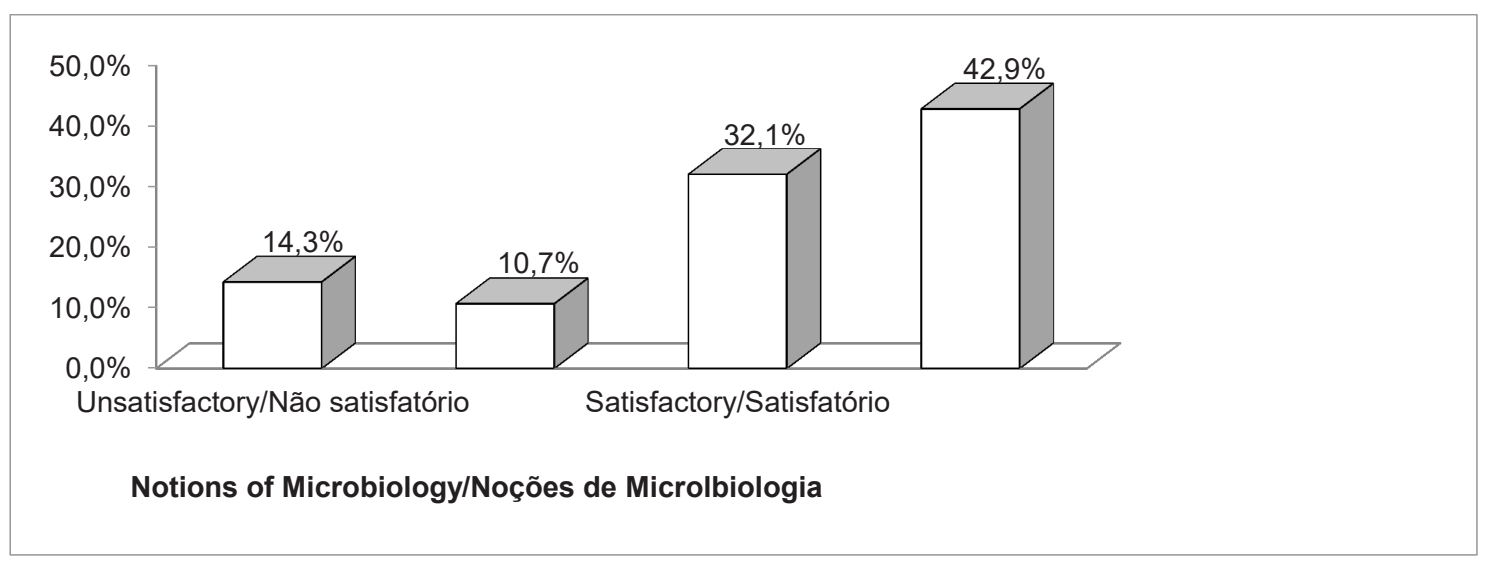

Figure 7 / Figura 7 - Distribution of dentistry professionals according to the notions of microbiology received during their training./ Distribuição dos profissionais de odontologia de acordo as noções de microbiologia recebidas durante a sua formação.

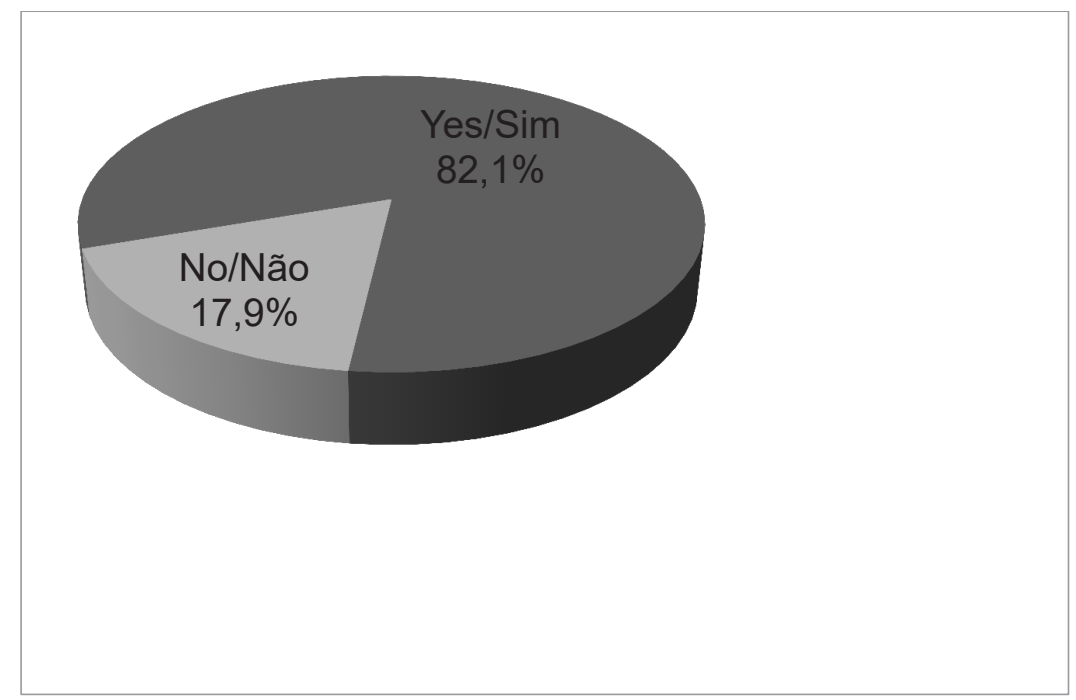

Figure 8/ Figura 8 - Distribution of dental professionals according to laboratory practice during their training./ Distribuição dos profissionais de odontologia de acordo a prática laboratorial durante a sua formação. 


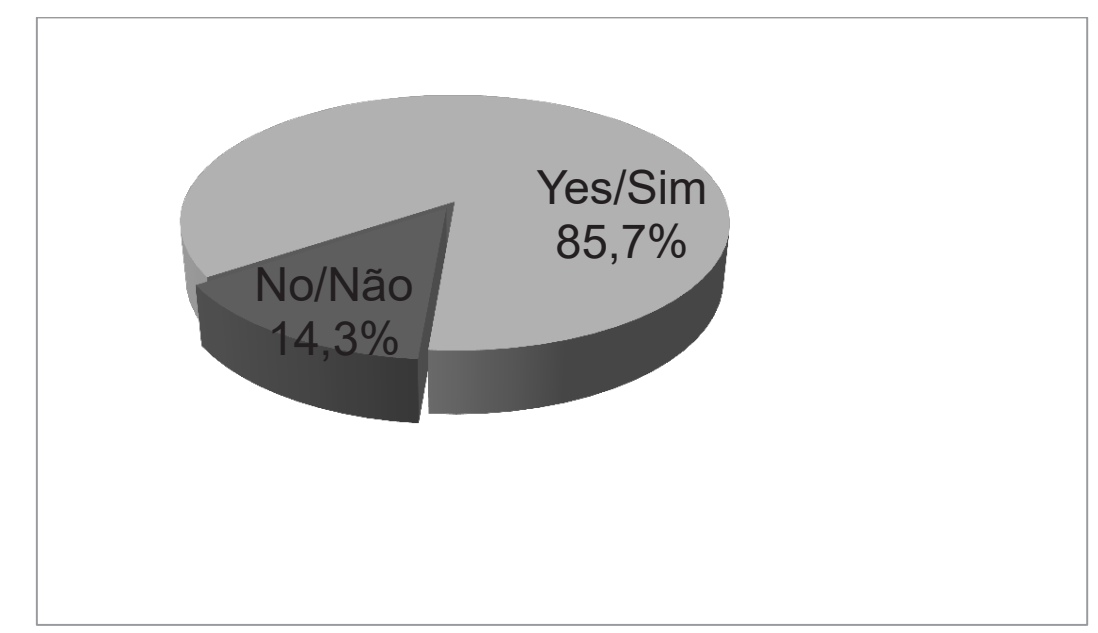

Figure 9/ Figura 9 - Distribution of dental professionals according to the classification of sufficiency of knowledge for the performance of daily activity/ Distribuição dos profissionais de odontologia de acordo a classificação da suficiência dos conhecimentos para o desempenho de atividade diária.

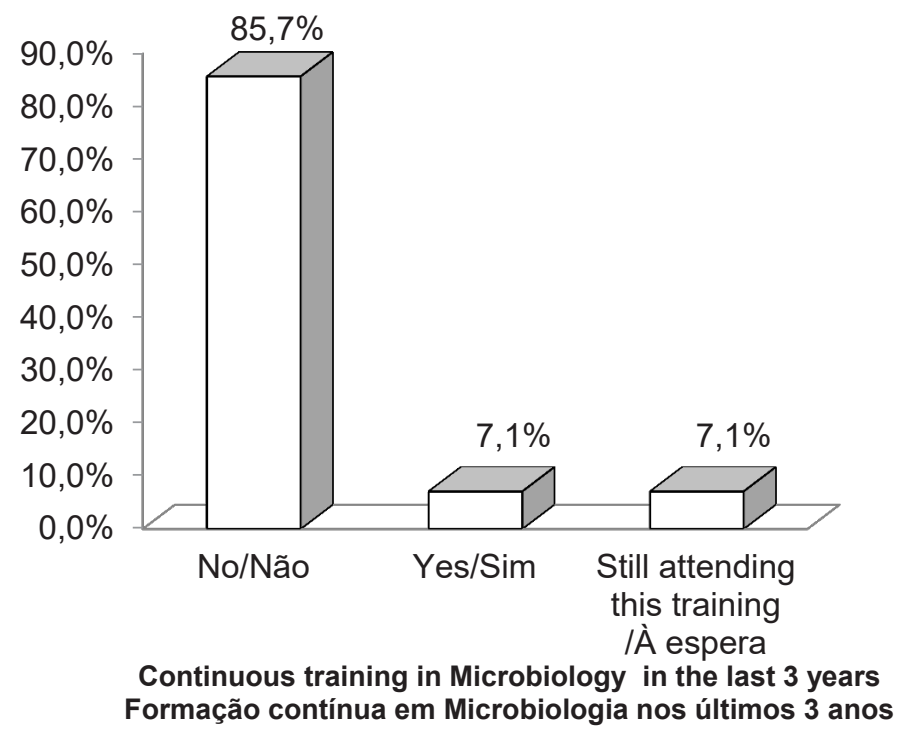

Figure 10/ Figure 10 - Distribution of dentistry professionals according to the benefit of continuous training in microbiology in the last 3 years./ Distribuição dos profissionais de odontologia de acordo o benefício de formação contínua em microbiologia nos últimos 3 anos. 
Regarding whether or not they participated in any Commission for the Control of Infection, the results indicate that $23(82 \%)$ of professionals and auxiliaries have not yet participated in any Commission for the Control of Infection, while $5(18 \%)$ already had. constatamos que 15 (54\%) já ouviu falar da Comissão de Controlo de Infeção e 13 (46\%) negam ter conhecimento da existência dessa comissão (Figura 11).

$\mathrm{Na}$ vertente de ter participado ou não em atividades de uma Comissão de Controlo de Infeção, os resultados indicam que 23 (82\%) dos profissionais e auxiliares ainda não tiveram uma participação em qualquer Comissão de Controlo de Infeção, porquanto 5 (18\%) já tiveram.

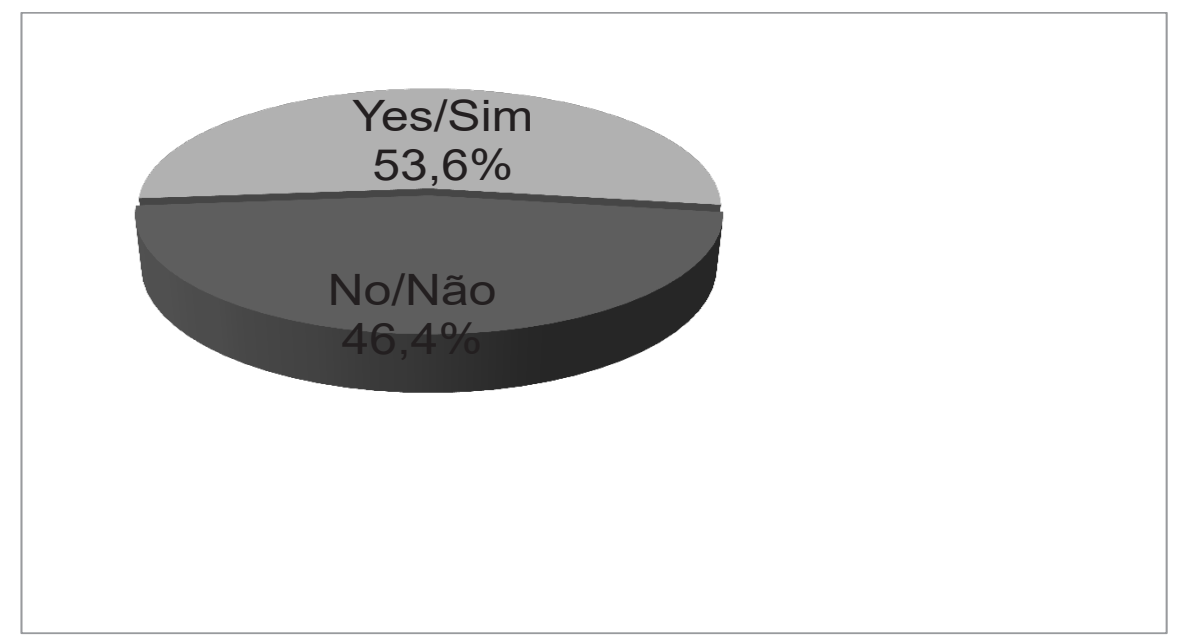

Figure 11/ Figura 11 - Distribution of dental professionals if you have ever heard of the Commission for the Control of Infection. /Distribuição dos profissionais de odontologia se alguma vez já ouviu falar da Comissão de Controlo de Infeção.

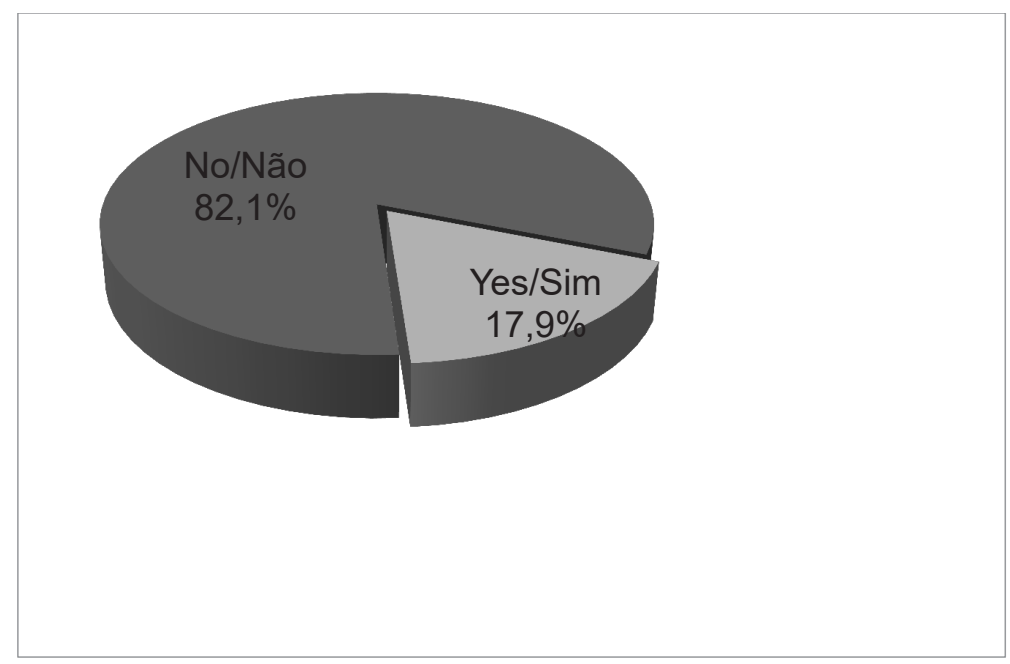

Figure 12/ Figura 12 - Distribution of dentistry professionals according to participation in a Commission for the Control of Infection. / Distribuicão dos profissionais de odontologia de acordo a participação em uma Comissão de Controlo de Infeção. 
Analysis of Managers' Opinions on Infection Control

Issues were addressed to managers of dental institutions (Table 1) to better understand the situation of infection control in those institutions providing health services. As a result, $71 \%$ of managers agree that their institutions implement the Infection Control Plan, $86 \%$ indicate that the institution has a Commission for the Control of Infection, 57\% agree with the existence and execution of the Plan of Infection Control. It was also verified that $71 \%$ of these institutions have Occupational Hygiene and Safety Offices and an equal percentage (71\%) confirm the existence of the Intervention Protocol on Occupational Accidents.

Of the same number of managers, $71 \%$ deny the existence of studies on microbiological mapping and the same percentage (71\%) refer to the failure to prepare the Reports on Control of Infection. Additionally, 57\% characterize that no models and no records of occupational accidents in those institutions have been reported.
Análise das Opiniões dos Gestores sobre o Controlo de Infeção

As questões foram dirigidas aos gestores das instituições odontológicas (Tabela 1) para se perceber melhor sobre a situação do controlo de infeção naquelas instituições de prestação de serviços de saúde. Em resultado, $71 \%$ dos gestores concordam que suas instituições implementam o Plano de Controlo de Infeção, 86\% indicam que a instituição possui uma Comissão de Controlo de Infeção, 57\% concordam com a existência e execução do Plano de Controlo de Infeção. Verificou-se também que $71 \%$ dessas instituições possuem Gabinetes de Higiene e Segurança no Trabalho e igual percentagem $(71 \%)$ confirma a existência do Protocolo de Intervenção em Acidentes Ocupacionais.

Do mesmo número de gestores, $71 \%$ negam a existência de estudos sobre mapeamento microbiológico e igual percentagem $(71 \%)$ refere a não elaboração dos Relatórios sobre o Controlo de Infeção. Adicionalmente, $57 \%$ caracterizam que não têm modelos e não têm sido reportados quaisquer registos de acidentes ocupacionais naquelas instituições.

Table 1/ Tabela - Distribution of the opinion of the 7 managers of dental institutions according to the plan, commission and reports on infection control/ Distribuição da opinião dos 7 gestores das instituições odontológicas de acordo com o plano, comissão e relatórios de controle de infecção

\begin{tabular}{|c|c|c|c|c|}
\hline \multirow[b]{2}{*}{ QUESTIONS/ QUESTÕES } & \multicolumn{4}{|c|}{ ANSWERS/RESPOSTAS } \\
\hline & $\begin{array}{l}\text { YES/ } \\
\text { SIM }\end{array}$ & $\%$ & NO/NÃO & $\%$ \\
\hline $\begin{array}{l}\text { Does the institution in which you have management } \\
\text { duties have the Infection Control Plan?/ A instituição } \\
\text { na qual é gestor tem o Plano de Controlo de Infeção? }\end{array}$ & 5 & $71 \%$ & 2 & $29 \%$ \\
\hline $\begin{array}{l}\text { Is there an Incident Control Committee?/ Existe uma } \\
\text { Comissão de Controlo de Infeção? }\end{array}$ & 6 & $86 \%$ & 1 & $14 \%$ \\
\hline $\begin{array}{l}\text { In your institution, are there studies on microbiological } \\
\text { mapping?/ Na Vossa instituição, existe estudos sobre } \\
\text { mapeamento microbiológico? }\end{array}$ & 2 & $29 \%$ & 5 & $71 \%$ \\
\hline $\begin{array}{l}\text { Is there a Training Plan on Infection Control?/ Existe } \\
\text { um Plano de Formação sobre o Controlo de Infeção? }\end{array}$ & 4 & $57 \%$ & 3 & $43 \%$ \\
\hline $\begin{array}{l}\text { Have the Infection Control Reports been prepared?/ } \\
\text { Têm sido elaborados os Relatórios sobre o Controlo de } \\
\text { Infeção? }\end{array}$ & 2 & $29 \%$ & 5 & $71 \%$ \\
\hline $\begin{array}{l}\text { Does your institution have a Section or Office of } \\
\text { Health and Safety at Work?/ A Vossa instituição conta } \\
\text { com uma Secção ou Gabinete de Higiene e Segurança } \\
\text { no Trabalho? }\end{array}$ & 5 & $71 \%$ & 2 & $29 \%$ \\
\hline $\begin{array}{l}\text { Are there models in place where occupational accident } \\
\text { records have been reported?/ Têm modelos onde têm } \\
\text { sido reportados os registos de acidentes ocupacionais? }\end{array}$ & 3 & $43 \%$ & 4 & $57 \%$ \\
\hline $\begin{array}{l}\text { Is there any protocol for intervention in occupational } \\
\text { accidents?/ Existe algum protocolo de intervenção em } \\
\text { acidentes ocupacionais? }\end{array}$ & 5 & $71 \%$ & 2 & $29 \%$ \\
\hline
\end{tabular}




\section{Search for significant correlations}

Using the Chi-Square test, Fisher's Exact test and the Mantel-Haenszel chi-square test, a measure was made of the association between the quality of the training of the respondents, the attending school and the participation in control of infection with the demographic variables age and gender. The results reveal that there was no statistically significant difference between the demographic and other variables in the above mentioned study presented values of $p>0.05$, that is, we found the following:

- Relationship between age and notions of microbiology $(\mathrm{p}=0.501)$

- Relationship between age and laboratory practice ( $\mathrm{p}$ $=0.207$ )

- Relationship between age and participation in Commission for the Control of Infection $(p=0.680)$

- Relationship between sex and notions of microbiology $(\mathrm{p}=0.410)$

- Relationship between sex and laboratory practice ( $p$ $=0.475$ )

- Relationship between sex and participation in Commission for the Control of Infection $(p=0.180)$

In the same way, and with the application of the same tests, correlations were made to measure the association between the degree of knowledge acquired during the initial and continuous training of dental professionals and auxiliaries and compliance with the measures of prevention of infections. The results presented in Tables 20, 21, 22 and 23 in the appendix in this study show that there are no statistically significant differences between the knowledge acquired during the initial and continuous training of dentists and dental assistants with non-compliance with the prevention of infection measures. Values higher than expected $(p>0.05)$ were observed, as follows:

- Relationship between the notions of microbiology received during the training in the school / university and participation in the Commission for the Control of Infection $(\mathrm{p}=0.288)$

- Relationship between laboratory practice during training and participation in the Commission for the Control of Infection ( $p=0.342)$

- Relationship between the sufficiency of knowledge acquired in the school / university for the performance of the daily professional activity and participation in the Commission for the Control of Infection $(p=0.432)$ - Relationship between continuous training in microbiology in the last 3 years and participation in the Commission for the Control of Infection $(p=0.393)$

Therefore, these results suggest that the initial and con-
Pesquisa de correlações significativas

Aplicando-se o teste do Qui-Quadrado, teste Exacto de Fisher e o teste do Qui-Quadrado Mantel-Haenszel, procedeu-se a uma medição da associação entre a qualidade da formação dos inquiridos, o estabelecimento de ensino frequentado e a participação em comissões de controlo de infeção com as variáveis demográficas: idade e género. Os resultados revelam de que não existiu diferença estatisticamente significativa entre as variáveis demográficas e outras em estudo acima mencionadas, apresentado valores de $\mathrm{p}>0,05$, ou seja, encontramos:

- Relação entre a idade e noções de microbiologia $(p=0,501)$

- Relação entre a idade e prática laboratorial $(p=0,207)$

- Relação entre a idade e participação em Comissão de Controlo de Infeção $(p=0,680)$

- Relação entre o género e noções de microbiologia $(p=0,410)$

- Relação entre o género e prática laboratorial $(p=0,475)$ - Relação entre o género e participação em Comissão de Controlo de Infeção $(p=0,180)$

Da mesma maneira, e com a aplicação dos mesmos testes, foram feitas correlações para se medir a associação entre o grau de conhecimento adquiridos durante a formação inicial e contínua dos profissionais e auxiliares de odontologia e a observância das medidas de prevenção de infeções. Os resultados demonstram não existirem diferenças estatisticamente significativas entre os conhecimentos adquiridos durante a formação inicial e contínua dos profissionais e auxiliares de odontologia com a não observância das ações de prevenção de infeção, tendo sido observados valores superiores ao esperado $(p>0,05)$, como a seguir se descreve:

- Relação entre as noções de microbiologia recebidas durante a formação na escola/universidade e a participação em Comissão de Controlo de Infeção $(p=0,288)$

- Relação entre prática laboratorial durante a formação e a participação em Comissão de Controlo de Infeção $(p=0,342)$

- Relação entre os conhecimentos adquiridos na escola/ universidade são suficientes para o desempenho da atividade profissional diária e a participação em Comissão de Controlo de Infeção $(p=0,432)$

- Relação entre benefício de formação contínua em microbiologia nos últimos 3 anos e a participação em Comissão de Controlo de Infeção $(p=0,393)$

Sendo assim, estes resultados sugerem que o défice de formação inicial e contínua dos profissionais e auxiliares de odontologia, não está na base da não observância das medidas de prevenção de infeções. 
tinuous training gap of dental professionals and dental assistants is not a basis for non-compliance with the measures to prevent infections.

\section{Discussion}

Responding to the questions of this research, namely (i) what is the knowledge of professionals and dental assistants regarding the infections transmitted during the dental practice? (ii) what is the observance of biosafety measures in dental practice in dental care units? and (iii) what is the perception and the reality of managers regarding the availability of PPE in dental care units?, it was verified that:

1. With regard to knowledge, assessed through training opportunities,

- initial, $75 \%$ of the professionals interviewed consider the training received as between satisfactory and totally satisfactory;

- continuous, $86 \%$ did not receive any training in the last 3 years;

Thus, it is verified that continuous training in microbiology is a process that is not implemented in the institutions where the individuals are located.

In an earlier study by Macosso ${ }^{[10]}$, only $11 \%$ of respondents were able to mention at least 7 transmissible diseases during dental practice, in contrast to the results of the present study, regarding the perception of knowledge acquired in schools. The lack of continuous training actions referred to by $86 \%$ of respondents, which is in contradiction to what is predicted in the literature, since it is in the performance of the functions that the experience regarding the prevention of infections is acquired ${ }^{[4]}$.

The fact that $86 \%$ of the respondents considered the knowledge about microbiology acquired during their training solid and that the same percentage did not benefit from any continuous training in the institution in which they are located, refers to Carvalho ${ }^{[11]}$, who says that many are the scientific activities that are full of uncertainties. In this sense, coherence and responsibility are necessary and the permanent search for total quality refers to the need for training, acquisition and mastery of knowledge for the execution of activities in order to ensure accuracy, validity, quality of results and maintenance of the integrity of persons, premises, machinery, instruments and equipment.

2. Regarding management, although it is documented from the opinion of professionals and managers, regarding the existence of hospital infection control committees and their operation, it is noted that there is no

\section{Discussão}

Respondendo às questões desta pesquisa, a saber (i) Qual o conhecimento dos profissionais e auxiliares de odontologia quanto às infeções transmitidas no decurso da prática odontológica? (ii) Que grau de observância das medidas de biossegurança na prática odontológica nas unidades de assistência odontológica? e (iii) Qual a perceção e a realidade dos gestores quanto a disponibilização de EPI's nas unidades de assistência odontológica?, verificou-se que:

1- Quanto ao conhecimento, avaliado através das oportunidades de formação,

- inicial, 75\% dos profissionais inquiridos consideram a formação recebida entre satisfatória e totalmente satisfatória;

- contínua, 86\% dos profissionais inquiridos não receberam nenhuma formação nos últimos 3 anos,;

verifica-se que, a formação contínua em microbiologia é um processo pouco implementado nas instituições onde os indivíduos se encontram colocados.

Num trabalho anterior de Macosso ${ }^{[10]}$, apenas $11 \%$ dos inquiridos conseguiram mencionar pelo menos 7 doenças passiveis de transmissão durante a prática odontológica, contrastando com os resultados da presente pesquisa, quanto à perceção dos conhecimentos adquiridos nas escolas de formação. O défice de ações de formação contínua referido por $86 \%$ dos inquiridos, o que está em contradição do previsto na literatura, pois é no desempenho das funções, que a experiência relativamente à prevenção das infeções, se vai adquirindo ${ }^{[4]}$.

O facto de $86 \%$ dos inquiridos considerarem sólidos os conhecimentos sobre a microbiologia adquiridos durante a sua formação e igual percentagem não ter beneficiado de nenhuma formação contínua na instituição onde se encontra, remete-nos ao pensamento de Carvalho ${ }^{[11]}$, que diz que muitas são as atividades científicas que se apresentam repletas de incertezas. Nesse sentido, coerência e responsabilidade se fazem necessárias e a busca permanente da qualidade total remete à necessidade de treinamento, aquisição e domínio de conhecimentos para a execução das atividades com vista a assegurar a precisão, a validade, a qualidade dos resultados e a manutenção da integridade das pessoas, das instalações, das máquinas, dos instrumentos e dos equipamentos.

2. No que diz respeito à gestão, apesar de se documentar a partir da opinião dos profissionais e gestores, quanto à existência de comissões de controlo de infeção hospitalar e do seu funcionamento, regista-se que não há mapeamento microbiológico nas instituições (71\%), nem a elaboração de relatórios sobre o controlo de in- 
microbiological mapping in institutions $(71 \%)$, nor the reporting of hospital infection control (71\%). The lack of this information will not allow us to warn about the existence of any risk of transmission of infection with documented agents if we also take into account the insufficient availability of PPE, as well as inefficiency of its use, also recorded in the above work by Macosso ${ }^{[10]}$. The lack of studies on microbiological mapping and the recognition of non-elaboration of the Reports on the Control of Infection alert to the lack of knowledge of critical points in the training of professionals, and in relation to biosafety, provide a potential intensification of the cycle of cross-infection ${ }^{[5,6]}$. Still, Runnells ${ }^{[11]}$ reinforces this position when he affirms that for years there are recommendations for the improvement of biosafety in the offices, but some of the professionals still prove resistant to questioning and to review the procedures regarding the adoption of measures of control of infection. In fact, the literature warns of the importance of this mapping for the detection of critical points. A study designed by Al-Hiyasat et al. ${ }^{[12]}$ to evaluate the extent of contamination of the Water from the Dental Unit (DUW) with Pseudomonas aeruginosa in a Dentistry Education Centre in Jordan led to the finding that $87 \%$ of dental units were contaminated with $P$. aeruginosa. In terms of training for professional practice, the results (Graph 7) suggest that the degree of transferability of the contents of the microbiology course in the health sciences teaching institutions in the country - in Luanda - is good. Failure to observe a statistically significant relationship between the knowledge acquired during initial and continuing training of dental professionals and auxiliaries and compliance with the prevention of infection measures disagrees with the research carried out in Luanda by Macosso ${ }^{[10]}$, whose objective was to evaluate the application by professionals and dental assistants of methods, means and equipment of biosafety in some dental care units, and where it was revealed that, in general, professionals and auxiliaries did not strictly observe the internationally recommended biosafety measures. The development of an initial map of prior understanding may follow several structural trajectories: (1) the existence of a qualitative variation in learning, and Kinchin and Cabot ${ }^{[13]}$ information acquisition without integration, (2) specialization of information such as isolated chains, (3) and, more desirable but difficult to measure, the integration of information into improved practices. feção hospitalar (71\%). A falta desta informação, não permitirá alertar sobre a existência de algum risco de transmissão de infeção com agentes documentados, se tivermos ainda em conta a insuficiente disponibilização dos EPI's, bem como ineficiência de seu uso, igualmente registada no supracitado trabalho de Macosso ${ }^{[10]}$. A exiguidade ou inexistência de estudos sobre mapeamento microbiológico e o reconhecimento de não elaboração dos Relatórios sobre o Controlo de Infeção alertam para o desconhecimento de pontos críticos na formação de profissionais e em relação à biossegurança, propiciando intensificação potencial do ciclo de infeções cruzadas ${ }^{[5,6]}$ reforça essa posição ao afirmar que há anos existem recomendações para a melhoria da biossegurança nos consultórios, mas parte dos profissionais ainda se mostra resistente a questionar e rever os procedimentos relativos à adoção de medidas de controlo de infeção. De facto, a literatura alerta para a importância deste mapeamento para deteção de pontos críticos. Um estudo desenhado por Al-Hiyasat et al., para avaliar a extensão da contaminação da Água da Unidade Odontológica (DUW) com Pseudomonas aeruginosa num Centro de Ensino de Odontologia na Jordânia, levou à constatação de que $87 \%$ das unidades odontológicas estavam contaminadas com $P$. aerugino$s a^{[12]}$

Em matéria de formação para o exercício profissional, os resultados (Figura 7) sugerem que o grau de transmissibilidade dos conteúdos da cadeira de microbiologia nas instituições de ensino das ciências de saúde no país - em Luanda - é bom. A não observação de uma relação estatisticamente significativa entre os conhecimentos adquiridos durante a formação inicial e contínua dos profissionais e auxiliares de odontologia e a observância das medidas de prevenção de infeções, discordam com os da pesquisa levada a cabo em Luanda por Macosso, ${ }^{[10]}$ cujo objetivo foi avaliar a aplicação pelos profissionais e auxiliares em odontologia de métodos, meios e equipamentos de biossegurança em algumas unidades de assistência odontológica, e onde se revelou que, em geral, os profissionais e auxiliares não observavam com rigor as medidas de biossegurança recomendadas internacionalmente. Indiscutivelmente, deve ser reconhecida a existência de uma variação qualitativa na aprendizagem, e Kinchin e Cabot ${ }^{[13]}$, relataram como o desenvolvimento de um mapa inicial de entendimento prévio pode seguir várias trajetórias estruturais: (1) aquisição de informações sem integração, (2) especialização de informações como cadeias isoladas, (3) e, mais desejável, mas difícil de medir, a integração de informação nas práticas melhoradas. 


\section{Conclusions}

A young population with an average age of 37 , mostly women and predominantly married, was surveyed in 7 units with dental assistance, of which 3 were public and 4 were private. They attended mostly high school in private schools (54\%) and the most frequent professional category was the Odontologists $(21 \%)$.

Good indicators of perception of the contents of the microbiology subjects transmitted in health science teaching institutions were obtained, and a great majority had laboratory practice during their training. Of the respondents, $86 \%$ believe that the knowledge acquired during training enables them to perform their daily activities, even though they have not had continuous training in microbiology in the last 3 years. The lack of continuous training by the respondents does not seem to influence compliance with the norms of infection control in those institutions, despite a behaviour of poor participation in Commission for the Control of Infections.

According to the results of this study, institutions through their managers attach great importance to infection control, since they have Plans and Commissions for Control of Infection, implement the Training Plans on Infection Control, have Occupational Health and Safety Offices, as well as have Protocols for Intervention in Occupational Accidents.

Possible weaknesses in dental practitioners 'and dentists' knowledge regarding the infections transmitted during dental practice may still be the basis for not carrying out studies on microbiological mapping, failure to prepare Infection Control Reports and lack of reporting of occupational accident records.

There was no correlation between the knowledge acquired during the initial and continuous training of dental professionals and auxiliaries and compliance with measures to prevent infections ( $p>0.05)$. However, it is a limitation of the present study not to have conducted biosafety audits, to be proposed in future studies in order to actively contribute to plans for continuous improvement.

\section{Conflict of interests}

The authors declare that there is no financial or personal relationship that can be understood as representing any potential conflict of interest.

\section{Conclusões}

Uma população jovem com uma média de 37 anos, maioritariamente mulheres e com predomínio de estado civil casado, foi inquirida em 7 unidades com assistência odontológica, das quais 3 públicas e 4 privadas. Frequentaram maioritariamente o ensino médio ou superior em escolas privadas (54\%), sendo a categoria profissional mais frequente a classe de Odontologistas (21\%).

Obtiveram-se bons indicadores de perceção dos conteúdos das disciplinas de microbiologia transmitidos nas instituições de ensino das ciências de saúde, e uma grande maioria teve prática laboratorial durante a sua formação. Dos inquiridos, 86 \% acredita que os conhecimentos adquiridos durante a formação, os capacita para o desempenho de suas atividades quotidianas, mesmo não tendo tido formação contínua em microbiologia nos últimos 3 anos. A falta de formação contínua pelos inquiridos, não parece influenciar o cumprimento das normas de controlo de infeção naquelas instituições, apesar de um comportamento da fraca participação em comissões de controlo de infeção.

De acordo os resultados deste estudo, as instituições através dos seus gestores atribuem grande importância ao controlo de infeção, pois têm Planos e Comissões de Controlo de Infeção, implementam os Planos de Formação sobre o Controlo de Infeção, têm Gabinetes de Higiene e Segurança no Trabalho, assim como têm Protocolos de Intervenção em Acidentes Ocupacionais. Possíveis debilidades do conhecimento dos profissionais e auxiliares de odontologia quanto às infeções transmitidas no decurso da prática odontológica, podem, ainda assim, estar na base da não realização de estudos sobre mapeamento microbiológico, a não elaboração dos Relatórios de Controlo de Infeção e ausência de relato dos registos de Acidentes Ocupacionais.

Não se observou correlação entre os conhecimentos adquiridos durante a formação inicial e contínua dos profissionais e auxiliares de odontologia e a observância das medidas de prevenção de infeções $(p>0,05)$. Contudo, é uma limitação do presente trabalho não ter realizado auditorias de biossegurança, a propor em futuros estudos no sentido de contribuir ativamente para planos de melhoria contínua.

\section{Conflito de interesses}

Os autores declaram que não existe uma relação financeira ou pessoal que possa ser entendida como representando um potencial conflito de interesses 


\section{References/ Referências}

1. Runnells, RR. An overview of infection control in dental practice. J Prosthet Dent 1988; 59: 625-629.

2. Jorge, AOC. Princípios de Biossegurança em Ondotologia. São José de Campos: Faculdade de Odontologia de São José de Campos/UNESP;1998.

3. ANVISA. Serviços Odontológicos: Prevenção e Controle de Riscos. 1ª ed. Brasília: Ministério da Saúde; 2006.

4. Guandalini SL, Melo NSFO, Santos E. Biosseguraça na Ondotologia-Controlo da Infeção Cruzada. $2^{\text {a }}$ ed. Panamá: Universidade Federal do Panamá; 2003.

5. Ferreira, RA. Barrando o invisível. Associação Paulista de Cirurgiões Dentistas 1995; 49: 417-27.

6. Pinto KML, Paula CR. Biosecurity Protocol at dental Office: Time and Cost. Rev biociênc Taubaté 2003; 9: 19-23.

7. Freitas RR. Biossegurança em Ondotologia. Minas Gerais: Universidade Federal de Minas Gerais; 2012.

8. Guandalini SL. Biossegurança. J Bras Odont Clin 1997; 1: 9-11.

9. Cottone JA, Molinari JA. Stade of the art infection control in dentistry. J Am Dent Assoc 1991; 122: 33-41.

10. Macosso T. Biossegurança: Importância dos Equipamentos de Proteção Individual, Métodos de Esterilização e Conservação de Materiais na Prevenção de Infecções em Odontologia. Angola: Universidade Privada de Angola; 2010.

11. Carvalho PR. O olhar docente sobre a Biossegurança no ensino de ciências: um estudo em escolas da rede pública do Rio de Janeiro. Rio de Janeiro: Instituto Oswaldo Cruz; 2008.

12. Al-Hiyasat AS, Ma'ayeh SY, Hindiyeh MY, Khader YS . The presence of Pseudomonas aeruginosa in the dental unit waterline systems of teaching clinics. Int J Dent Hyg 2007; 5 36-44.

13. Kinchin IM, Cabot, LB. An introduction to concept mapping in dental education: The case of partial enture design. Eur J Dent Educ 2009; 13: 20-27. 